\title{
Antecedent and Consequence of Customer Company Identification toward Relationship Marketing at PDAM Tirta Khatulistiwa Pontianak, West Kalimantan Indonesia
}

\author{
Nur Afifah ${ }^{1 *}$ and Ilzar Daud ${ }^{2}$ \\ 1,2Management Study Program, Faculty of Economic and Business, University of Tanjungpura, 78124 Pontianak, West Kalimantan \\ Indonesia.
}

\begin{abstract}
Objective -This study sets out to examine the conceptual framework and empirical test of CCI toward on the PDAM Tirta Khatulistiwa Pontianak, West Kalimantan Indonesia. It is also keen to explore how customers identify the company and what the antecedents and consequences of the identification which will give impact on customer relationships. This study contributes to the practical and scientific marketing that the identification of customers to the company can be used by company to make products that match customer expectations. Furthermore, the presence of CCI can be used by the company to establish marketing relationships with the customers.

Methodology -This study is explanatory approach, 210 customers from three service areas were recruited as participants. The study used SEM inferential statistical approach where Smart PLS program was used as the analysis technique.

Findings -Results of this study showed that: Customers of PDAM Tirta Khatulistiwa identify companies based on five dimensions, including; external company image, employee in services, company's products, characteristics of the company and the technology used by the company. In addition consequences of CCI is positive for relationship marketing. Finally, employee in services, products the company, and technology used by the company has contributed to the development of CCI.
\end{abstract}

Novelty - The study put emphasize with its original data on building resource-based strategy (RBV).

Type of Paper: Empirical

Keywords: Identification; Social Identity Theory; Customer Company Identification; Relationship Marketing.

JEL Classification: L12, L21, M14.

\section{Introduction}

To date several studies have documented the impact of customer company identification (CCI) (Hildebrand et al., 2010; Yuan 2011; Arikan \& Guner, 2013; Martinez \& Bosque, 2013; Sommerfeld \& Paulssen, 2015,

\footnotetext{
* Paper Info: Received: November 16, 2016

Accepted: May 14, 2017

* Corresponding author:

E-mail: afifahnur_fe@yahoo.com

Affiliation: University of Tanjungpura, Indonesia
} 
Afifah \& Afandi, 2015). This study is conducted in the public sector (PDAM), and not only analyzes the consequence of CCI, but also builds a model of the antecedent of CCI. Then, the study tests the models of CCI antecedent which is related to relationship marketing in PDAM Tirta Khatulistiwa Pontianak, West Kalimantan Indonesia.

PDAM Tirta Khatulistiwa Pontianak, West Kalimantan, Indonesia is one of the public services which, has a very important role in supplying tap water to citizens in Pontianak. Hence it is very important to explore customer perception toward company since. In because public participation plays a very important role in the process of innovation and improvement in public services. (Piening, 2013; Beata et al., 2015).

Customer identification will assist the company to meet the market's need and expectation (Bhattacharya and Sen, 2003). The company can design products and services to suit customers' expectations because CCI could impact on customer satisfaction and loyalty (Cedric \& Hung; 2011; Arikan \& Guner, 2013; Kang June et al., 2015; Sommerfeld \& Paulssen, 2015, Afifah \& Afandi, 2015).

Customer satisfaction and loyalty are constructing to build strong customer relationships (Morgan \& Hunt, 1994; Anabila et al, 2012; Chakiso, 2015). A company can build customer relationships, committed through the identification of the customer to the company (Cedric \& Hung, 2011). Therefore, a strong marketing relationship between the customer and the company often comes from the customer identification to the company.

The study sets out to examine the conceptual framework and empirical test CCI on the PDAM Tirta Khatulistiwa Pontianak, West Kalimantan Indonesia. In addition, the study is keen to explore how customers identify the company. Finally, it aims at investigating what antecedents and consequences of the identification which will give impact on customer relationships. This study contributes to the practical and scientific marketing that the identification of customers to the companies can be used by company to make products that match customer expectations. Furthermore, the presence of CCI can be used by the company to establish marketing relationships with customers.

\section{Literature Review}

\subsection{The Conceptual Bases of the Theory of Social Identity}

Behavior and attitude will become the object of study in the field of psychology since the 19th century (Hildebrand et al., 2010). It has received much attention both from practitioners and academics to find the motive why people form groups and social institution. Up to present, the theory of social identities is perceived as one of the most widely used approaches to study the formation of self-concept, individuals perform cognitive observations in an attempt to determine their identity (Sirgy, 1982). This effort is done to affirm the continuity of the individual's self- concept from time to time and to try distinguish one-self with others (Whetten and Godfrey, 1998).

Social identity theory suggests that people articulate a sense of oneself (i.e, self-concept) to develop a social identity (Tajfel \& Turner, 1985). Membership in various social classes (e.g. gender, ethnicity, and occupation) and associations with various organizations important sources of social identity. Organizational identification occurs when a person feels a sense of connectedness with an organization and begins to define themselves in terms of organization (Mael \& Ashforth, 1989).

\subsection{The Conceptual Bases of Customer Company Identifications (CCI).}

Customer identification to the company is developing a concept which is based on the social identification theory (Brewer, 199; Tajfel and Turner, 1985), employee identification (Bergami and Bagozzi, 2000; Dutton et al., 1994), which is developed with the concept of customer identification of the company known as CCI (Bhattacharya and Sen, 2003). Several researchers have conducted myriad research in this field (Hildebrand et al., 2010; Arikan and Guner, 2013; Sommerfeld and Paulssen, 2015). 
Some studies (Arikan \& Gunar, 2013, Afifah \& Afandi, 2015), suggest that CCI has an influence customer loyalty. On the other hand, there are other studies claiming that CCI indirectly affects the customer loyalty, but it is through customer satisfaction (Martinez \&Bosque, 2013). Customer satisfaction and loyalty are two constructs to build strong customer relationships (Morgan \& Hunt, 1994; Anabila et al, 2012; Chakiso, 2015). A strong relationship between the customer and the company often comes from the identification of the customer to the company.

CCI is a state of self-cognition, categorization, connection and closeness of consumers with companies which is carried by the subjective process of comparison between the organization's identity and the identity of the consumers themselves (Martinez \& Bosque, 2013). In the other words, cognitive, connection and closeness imply a perception between organizations and personal identity, where the existence of shared values play an important role. Thus, the CCI is derived from the psychological condition attached to the consumer so that consumers become concerned about companies that positively stimulate their loyalty to the company. This is because the CCI as a psychological substrate that produces a deep relationship, committed and highly influential among customers and organizations (Bhattacharya \& Sen, 2003). Therefore, so individuals have a tendency to identify the company and there is always a consequence of the activities carried by the identification.

\subsection{Empirical Model and Hypothesis Testing.}

This study is an empirical test of antecedent and consequent CCI toward relationship marketing at PDAM Tirta Khatulistiwa Pontianak, West Kalimantan Indonesia. The concept developed in this study is based on the concept of customer experience (Payne et al., 2008; Verhoef et al, 2009). It is a journey where the customer before, after, even after having in touch with the company. This customer journey, can be termed as "communication encounter, encounter usage and service encounter". Therefore, in each trip, customers get a multi-faceted response: cognitive, affective, emotional, social and physical. Hence in each stage, customer identification and evaluation not only lies in the quality of products or services, but also assesses overall products and services, the employees as well as business processes and technologies (Beevers, 2000; Lovelock 2012; Munhurrum et al., 2010; Chang \& Horg 2010; Greenwel et al., 2012; Afifah et al., 2015).

Customers of PDAM Tirta Khatulistiwa Pontianak, also believe that a company has a set of distinctive characteristics, for example, culture, strategy, technology, employees, and products produced (Chang \& Horg 2010; Greenwel et al., 2012; Afifah et al., 2015) which is attractive to be identified, so that the stronger the identification of the customer against the company, the stronger the CCI will be (Bhattacharya \& Sen, 2003). Therefore, the CCI has an effect on customer satisfaction and loyalty (Cedric \& Hung; 2011; Arikan \& Guner, 2013; Jun et al., 2015; Sommerfeld \& Paulssen, 2015). Their satisfaction and loyalty of customers is a construct to build strong customer relationships (Morgan \& Hunt, 1994; Anabila et al., 2012). A strong relationship between the customer and the company often comes from the identification of the customer to the company (Bhattacharya \& Sen, 2003).

There are five hypotheses proposed in this research, H1: The stronger customers interpret the external image of PDAM Tirta Khatulistiwa Pontianak, the stronger the CCI. H2: The stronger customer services interpret employee PDAM Tirta Pontianak, the stronger the CCI. H3: The stronger the customers interpret the services of PDAM Tirta Khatulistiwa Pontianak, the stronger the CCI. H4: The stronger customers interpret the characteristics of the PDAM Tirta Khatulistiwa Pontianak, the stronger the CCI. H5: The stronger the customers interpret the technology used in PDAM Tirta Khatulistiwa Pontianak, the stronger the CCI. H6. CCI influence on relationship market. See figure 1 to look at the details of the conceptual research framework. 


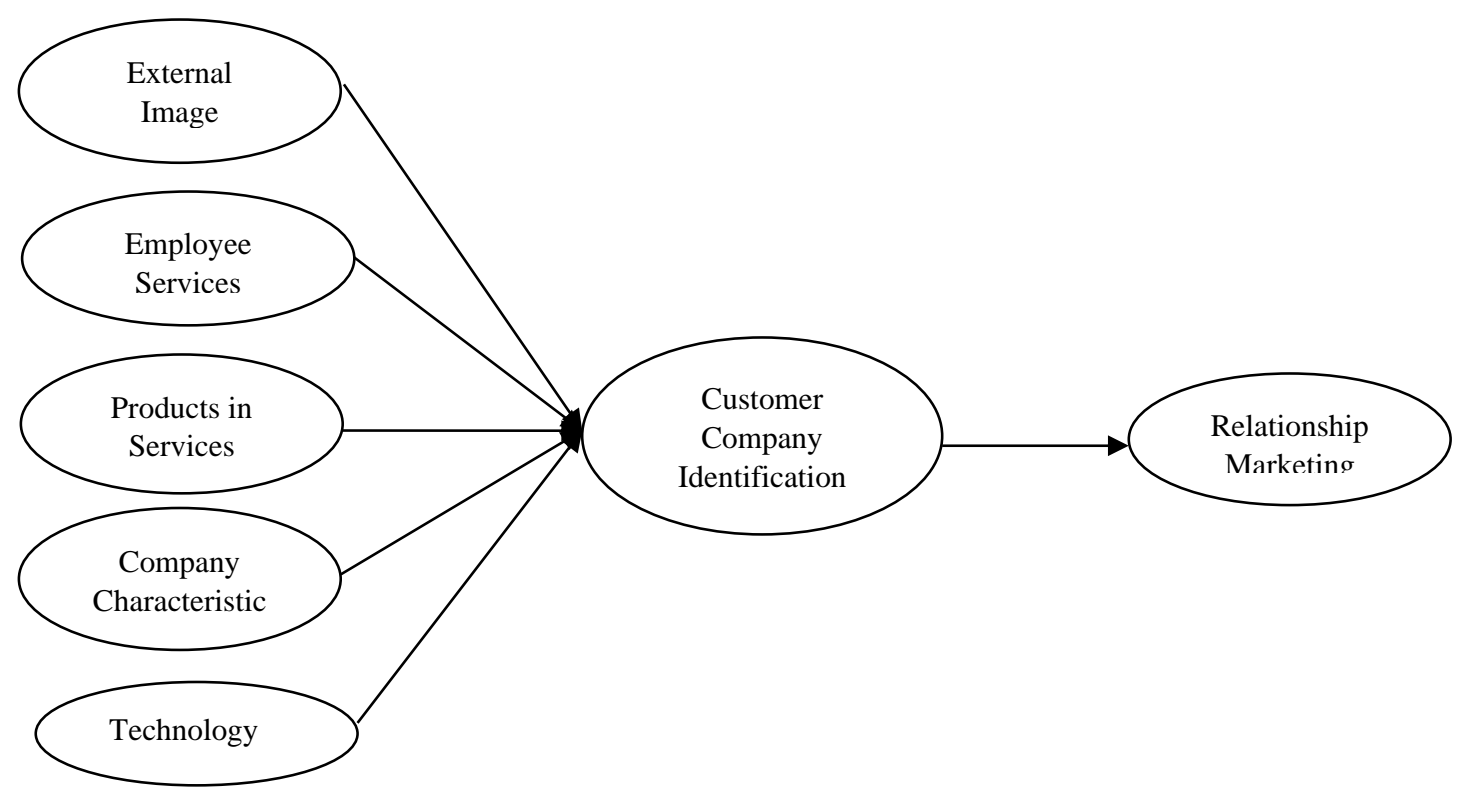

Figure 1. Research Framework.

\section{Research Methodology}

This study used an explanatory approach, 210 customers from three service areas were recruited as participants through incidental technique sampling. For data analysis the study used SEM (structural equation modeling) where the Smart PLS program (partial least square) was selected as the analysis technique.

\section{Results}

To test the hypothesis that has been determined, we should firstly look at the value of $\mathrm{T}$ statistics, where the $95 \%$ level of confidence should be higher than 1.96 or $\mathrm{P}$ value should be less than 0.05 . Hance it can be interpreted that its influence is significant. Table 1 below shows the results of hypothesis testing.

Based on the statistical tests: $\mathrm{H} 1$ and $\mathrm{H} 3$ did not affect the establishment of CCI, because the $\mathrm{P}$-Value > 0.05. Meanwhile the H2, H4 and H5 were influential in the formation of CCI on PDAM Tirta Khatulistiwa Pontianak, because $\mathrm{p}$-Value $<0,05$. It indicated that the employee services, products and technology services company that used by PDAM Tirta Khatulistiwa Pontianak. While H6, as the consequence of the CCI can the relationship marketing, because $\mathrm{p}$-Value $<0.05$.

Table 1. Results of Hypothesis Testing

\begin{tabular}{|l|c|l|l|l|}
\hline \multicolumn{1}{|c|}{ Causality relations } & $\begin{array}{c}\text { coefficient } \\
\text { path }\end{array}$ & T-Statistic & p-Value & Result \\
\hline Eksternal Imag $\rightarrow$ CCI & 0.146 & 1.596 & 0.112 & Insignificant \\
\hline Employe Services $\rightarrow$ CCI & 0.280 & 3.344 & 0.001 & Significant \\
\hline Product in services $\rightarrow$ CCI & 0.363 & 3.248 & 0.000 & Significant \\
\hline Company Characteristic $\rightarrow$ CCI & 0.144 & 1.535 & 0.111 & Insignificant \\
\hline Technology $\rightarrow$ CCI & 0.235 & 2.878 & 0.0022 & Significant \\
\hline CCI $\rightarrow$ Relationship Marketing & 0.345 & 3.346 & 0.000 & Significant \\
\hline
\end{tabular}




\section{Discussion}

This study aims to examine the conceptual framework and empirical test of how customers identify PDAM Tirta Khatulistiwa. In addition, the study tries to explore what antecedents and consequences of the identification which will impact on customer relationships. This study contributes to customer identifications on PDAM Tirta Khatulistiwa, which are external image, employee services, products, services, characteristics of the company and the technology used. The antecedent which form CCI, where employee services, products and technology services, while the CCI consequence has an influence on relationship market. This study also contributes to the literature on social identity theory (Tajfel and Turner, 1985), demonstrating the role of CCI on customer behavior.

PDAM Tirta Khatulistiwa holds a monopoly right to provide clean water for the community. In order to carry out its function as a public sector, the company is required to allocate strategic resources, create public value (Bekkers et al, 2013; Pee and Kankanhalli. 2015).

\section{Conclusion}

Employee services, products and technology services are an antecedent in the formation of CCI. CCI consequences have an influence on the relationship marketing at PDAM Tirta Khatulistiwa Pontianak, West Kalimantan Indonesia. Therefore, the management must be capable optimizing their strategic resources. This is consistent with the RBV (resources-based vie) approach by Barney (1992). The key success of public organizations is to build a resource-based strategy (RBV) owned by the organization to meet the needs of customers and stakeholders.

\section{Acknowledgements (Optional)}

I would like to thank the Faculty of Economics and Business, University of Tanjungpura, employee and heads of PDAM Tirta Khatulistiwa Pontianak, West Kalimantan Indonesia.

\section{References}

Afifah N., \& Afandi A. (2015). The impact of CSR, services experience and intercultural competence on customer company identification, customer satisfaction and customer loyalty (case study: PDAM Tirta Khatulistiwa Pontianak West Kalimantan). Procedia - Social and Behavioral Sciences, 2(11), 277-284.

Afifah N., Ahmad, S., \& Ilzar D. (2015). Perception on the service experience: An exploration of public sector in PDAM Tirta Khatulistiwa Pontianak West Kalimantan using reportary Grid Technique. Global Journal of Business and Social Science Review, 4(1), 80-88.

Anabila, P. N. B., \& Tweneboah-Koduah, E. (2012). Relationship marketing practices and customer loyalty: Evidence from the banking industry in Ghana. European Journal of Business and Management, 4(13), 304-313.

Arikan E., \& Guner S. (2013). The impact of corporate social responsibility, service quality and customer- company identification on customers. Procedia - Social and Behavioral Sciences, 99, $304-313$.

Barney, J. B. (1991). Firm resources and sustained competitive advantage. Journal of Management, 17 (1), 99-120.

Beata, M. I., Merickova, I. M. B., Emec, N. J, \& Svidronova, M. (2015). Co-creation in local public rervices delivery innovation: Slovak experience. Lex localis - Journal of Local Self-Government, 13(30), 521 - 535.

Beevers R. (2000). Customer service excellence in the publik sector. Northem Housing Concortium.

Bekkers, V. J. J. M., Tummers, L. G., Stuijfzand, B. G \& Voorberg, W. (2013). Social innovation in the public sector: An integrative framework. LIPSE Working papers 1 (Rotterdam: Erasmus University Rotterdam).

Bergami, M., \& Bagozzi, R. P. (2000). Self- categorization, affective commitment, and group self-esteem as distinct aspects of social identity in the organization. British Journal of Social Psychology, 39, 555-577.

Bhattacharya, C. B., \& Sen, S. (2003). Consumer- company identification: A framework for understanding consumers' relationships with companies. Journal of Marketing, 67(2), 76-88. 
Brewer, M. B. (1991). The social self: On being the same and different at the same time. Personality and Social Psychology Bulletin, 17, 475-482.

Cedric, H., \& Hung L.W. (2011). The study of the relationships among consumer-company identification, service encounter factor and customer satisfaction. Procedia - Social and Behavioral Sciences, 99, $104-114$.

Changa, Y., \& Horng, C. (2010). Conceptualizing and measuring experience quality: the customer's perspective. The Service Industries Journal, 30 (14): 2401-2419.

Chakiso, B. C. (2015). The effect of relationship on customer's loyalty (Evidance from Zemen Bank). Emerging Market Journal, 5(2), 78-85.

Dutton, J. E., Dukerich, J. M., \& Harquail, C. V. (1994). Organizational images and member identification. Administrative Science Quarterly, 39, 239-263.

Greenwell, T, Christopher, J. S. F., \& Donna L. P. (2012). Perceptions of the service experience: using demographic and psychographic variables to identify customer segments. Sport Marketing Quarterly, 11(4), 735 - 442.

Hildebrand, D. F N., Fernandes, D., Veloso A. R., \& Slongo L. A. (2010). Consumer-company identification: Development and validation of a scale. BAR, Curitiba, V.7, n.3, art, 276 -293.

Jun, K., Brasear, A. T. \& Groza, M.D. (2015). Customer company identification and the effectiveness of loyalty program. Journal of Business Research, 68, 464-467.

Lovelock. (2012). Market orientation and business performance: a framework for services organization. Thomson, South-Western.

Mael F., \& Ashforth B.E. (1989). Social identity theory and the organization. Academy of Management Review, 14(1), 20-39.

Martinez P., \& Bosque, I. R. B. (2013). CSR and customer loyalty: The roles of trust, customer identification with the company and satisfaction. International Jurnal of Hospitality Managemet, 35, 89-99.

Morgan, R. M., \& Hunt. S. D. (1994). The commitment-trust theory of relationship marketing. Journal of Marketing, 58, 20-38.

Munhurrun, P. R., Bhiwajee, S. D. L., \& Naido P. (2010). Service quality in the public service. International Journal of Management and Marketing Research, 3(1), 123-132.

Payne, A., Storbacka, K., \& Frow, P. (2008). Managing the co- creation of value. Journal of the Academy of Marketing Science, 36, 83-96.

Pee, L.G \& Kankanhalli. (2015). Interactions among factors influencing knowledge management in public sector organizations: A resource-based view. Goverment Information Quartely xxx-xxx.

Piening, E.P. (2013). Dynamic capabilities in public organizations: A literature review and research agenda. Public Management Review, 15(2), 209-245.

Sirgy, J.M. (1982). Self-concept in consumer behavior: a critical review. Journal of Consumer Research, 9(3), 287300.

Sommerfeld., \& Paulssen M. (2015). Understanding customer-company identification and its impact on customer in- and extra-role behaviours in a retail setting. Phd Dissertation, Department of Business Administration, Humboldt University Berlin.

Tajfel, H., \& Turner, J. C. (1985). Psychology of intergroup relations. Chicago: Nelson-Hall.

Verhoef, P., Lemon, K. N., Parasuraman, A., Roggeveen, A., Tsiros, M., \& Schlesinger, L. A. (2009). Customer experience creation: determinants, dynamics and management strategies. Journal of Retailing, 85, 31-41.

Whetten, D. A., \& Godfrey, P. C. (1998). Identity in organization: Building theory through conversations. Thousand Oaks, CA: Sage Publications.

Yuan, S. L. (2011). The effect of corporate social responsibility (CSR) initiatives on consumer identification with companies. African Journal of Business Management, 5(5), 1642-1649. 